\title{
Estimating Anticipated Performance Index and Air Pollution Tolerance Index of Some Trees and Ornamental Plant Species for the Construction of Green Belts
}

\author{
Saadullah Khan Leghari², Ali Akbar³, Said Qasim ${ }^{4}$, Sami Ullah $^{5}$, Mudassir Asrar², \\ Huma Rohail ${ }^{6}$, Sheikh Ahmed ${ }^{6}$, Khalid Mehmood ${ }^{6}$, Imran Ali ${ }^{1,6,7 *}$ \\ ${ }^{1}$ School of Life Sciences and Engineering, Southwest University of Science and Technology, Mianyang, China \\ ${ }^{2}$ Department of Botany, University of Balochistan, Quetta, Pakistan \\ ${ }^{3}$ Department of Microbiology, University of Balochistan, Quetta, Pakistan \\ ${ }^{4}$ Department of Geography, University of Balochistan, Quetta, Pakistan \\ ${ }^{5}$ Department of Chemistry, University of Balochistan, Quetta, Pakistan \\ ${ }^{6}$ Institute of Biochemistry, University of Balochistan, Quetta, Pakistan \\ ${ }^{7}$ Plant Biomass Utilization Research Unit, Department of Botany, Chulalongkorn University, Bangkok, Thailand
}

Received: 20 June 2017

Accepted: 27 March 2018

\begin{abstract}
This study combines air pollution tolerance index (APTI) and anticipated performance index (API) in order to determine the potential of trees and ornamental shrubs that are frequently growing on the roads of Quetta, Pakistan, and the campus of the University of Balochistan, in Quetta, for green belt development. Our investigation exposed that not only APTI is suitable for the fitness of trees for building green belts. It is used to categorize vulnerable plant species for only bio-monitoring. The grouping of APTI and API in the present study is a practical technique for decreasing air pollution control. Laboratory analysis for APTI was carry out by the four physico-biological factors such as leaf extract $\mathrm{pH}$, total chlorophyll content, ascorbic acid content, and relative water content. API for different plant species (trees and ornamental shrubs) was determined depending upon the characteristic grading by allotted + or - to the plants. The standard for determining API is given in Table 2. For examining the relationships among these factors statistics were utilized. This study indicated that the APTI is used as an instrument for choosing suitable plants to reduce environmental urban heat. API designated that Morus alba L., Pinus halepensis Miller, Ficus carica L., and Pistacia vera L. with API $=6$ are excellent performers for green belt development. Morus nigra L. and Malus pumila Miller had API 5 and are considered very good performers, and Fraxinus angustifolia Vahl., Prunus armeniaca L., and Platycladus orientalis L. showed 4 API values with good performance for green belt formation. All the other remaining investigated trees and ornamental shrubs demonstrated poor values of API
\end{abstract}

*e-mail: imranalisheik@gmail.com 
and are not recommended for green belts as they act as bio-indicators. Data also exhibited that all the examined trees had higher API values then the ornamental shrubs. This study suggested that the integration of both APTI and API of plants is extremely beneficial for the construction of green belts.

Keywords: Quetta city, APTI, API, trees, ornamental shrubs, green belt, air pollution

\section{Introduction}

Shadow produced by vegetation contributes to reducing heat released in urban areas and also intercepts radiation. The reaction of vegetation to air pollutants fluctuates depending on species. Mostly air pollution is caused by anthropogenic activities such as burning of solid waste (hospital and household waste), partial burning of fossil fuels, and firewood, etc. The solid waste is usually burnt by the local farmers close to their agricultural fields. This is hazardous for all kinds of plants' morphology and physiology [1]. APTI is based on four biochemical parameters such as chlorophyll content, leaf extract $\mathrm{pH}$, and relative water content and ascorbic acid in leaf samples [2]. APTI determination provides a reliable method for screening large numbers of plants with respect to their susceptibility to air pollution [2]. The more lenient plants on the basis of APTI are considered suitable utensils for the urban environment to decrease the air pollution and anticipated performance index worth is utilized to estimate the fitness of plant species for green belt formation [3, 4]. Anticipated performance index, stand on the collective consequences of a number of socioeconomic and biological feature like height of plant, structure of canopy, size of plant, hardness, and texture of plants [5]. While the consequences of air pollutants on biochemical parameters of plants are evaluated by APTI, API is used to judge the capabilities of predominant species to clean up atmospheric pollutants. Govindaraju et al. [6] exhibited that for the growth of green belt in order to fight against air pollution, anticipated performance index is very important, which is reflected by some biological and socioeconomic characteristics of the plants. So API is more effective then APTI. The use of any single parameter for determining the sensitivity of any plant against air pollution may not give a clear picture induced by air pollutants in the plant species. Thus the assessment of APTI and API of the plants are being used to categorize as sensitive to tolerant. During the up gradation of urban warmth at microscale the street/road ornamental shrubs and trees play highly sentimental roles. In the urban atmosphere ornamental shrubs decrease city warmth via cold air sheet over them by means of the transpiration processes, while tree species with shade condense the altitude of high temperatures on the urban facade. Plants are among natural sources that help reduce air pollution. In plants, leaves play a vital role in absorbing gases and some particulate matter. Therefore, vegetation acts as the natural cleanser of pollution in the atmosphere
[7]. The detoxification of air is one of the important aptitudes of vegetation. The investigation of Rai and Panda [8] indicated that the tolerant species plays a role in reducing overall pollution, and sensitive species can be regarded as primitive indicators of pollution. Green belts are recognized as effective tools for alleviating air pollution [3]. Our experimental zone (Quetta city and the University of Balochistan, Quetta) is situated in a beautiful mountainous region that is densely populated. It is situated in a river valley close to Bolan Pass, which is being used as a way of starting coastal region of Indus Sea to middle Asia, passing from the region of Afghanistan's area. Quetta has 3 big hills Zarghoon, Koh-e-Murdar, and Chiltan - which look like an umbrella over this beautiful city. In spite of all its charm, Quetta is facing numerous environmental challenges. Because of severe vehicular activities in Quetta, pollution levels have been raised to a shocking condition in recent decades [9]. Vegetation of Quetta and the university are exposed to a diversity of air contaminants.

This study was carried out in order to assess the API and APTI of some frequently grown trees and ornamental shrubs at urban sites in Quetta and the University of Balochistan for the growth of green belts.

\section{Materials and Methods}

\section{Experimental Area}

Research areas comprised three regions: Quetta city, the campus of the University of Balochistan, and Urak Valley Quetta Balochistan, Pakistan. The investigated areas were divided in to 2 zones: the investigational zone (Quetta city and Campus University of Balochistan) and the control site (Urak Valley). Characteristics of the study areas are outlined below.

\section{Experimental Sites}

Quetta is the capital of Balochistan Province, located at $30.1830^{\circ} \mathrm{N}, 66.9987^{\circ} \mathrm{E}$ latitude and longitude (Fig. 1a). Its height above sea level is about $1676 \mathrm{~m}$. The type of weather of the city is normally arid and chilly. Generally the greatest precipitation and snowstorms happen in the months of January and February. Summer remains modest; at the same time, June and July are the warmest by highest temperatures $\left(32^{\circ} \mathrm{C}\right.$ to $\left.20^{\circ} \mathrm{C}\right)$ [9]. The university of Balochistan Quetta is located at the main Sariab Road in Quetta (Fig. 1b). The University 

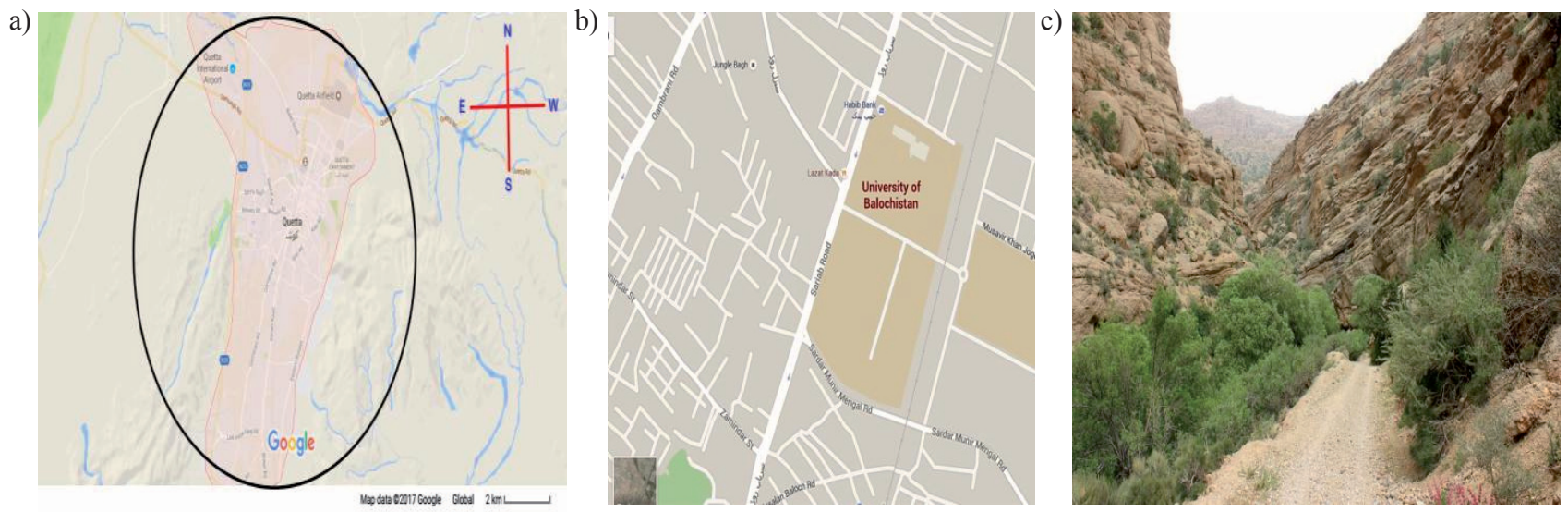

Fig. 1. a) Satellite view of Quetta city (source: Google Maps), b) Satellite view U.o.B, Quetta, c) View of Urak Valley Quetta (source: Google Maps).

of Balochistan is the mother University of Balochistan Province and is the heart of education because of the presence of student hostels, a medical center, and staff residences, therefore traffic density remains high at the university.

\section{Control/Reference Urak Valley}

Urak Valley is a remote area of Quetta District. It is located near the well-known Hana Lake and is $21 \mathrm{~km}$ from Quetta city (Fig. 1c) with minimal traffic density (government of Balochistan: Urak-Valley).

\section{Collection of Leaf Samples}

Leaf samples of 20 different plant species (trees and ornamental shrubs) $M$. alba L., M. nigra L., F. angustifolia Vahl., R. pseudoacacia L., P. halepensis Miller., P. armeniaca L., F. carica L., M. pumila Miller, $P$. orientalis L., P. vera L., R. indica, M. jalapa L., G. rotandifolium L., $C$. indica L., D. barbeyi (Huth), R. acraeus, P. somniferum L., O. basilicum L., J. grandiflorum L., and $S$. alopecuroides L. from experimental sites (Quetta city and campus area of the university) and control site (Urak Valley) that were predominantly common at both regions were collected from iso-ecological conditions (light, water, and soil) following the standardized methods of Ara et al. [10]. Fully mature trees and ornamental shrubs were selected for sampling. About $1 \mathrm{~kg}$ (trees) and $1 / 2 \mathrm{~kg}$ (shrubs) fresh leaf samples were taken from each individual of a species from three different height positions on the plant (10 leaves from each position), representing three discrete leaf age classes, i.e., a young, expanding leaf on the upper portion of the plant; a mature, fully developed leaf near the middle portion of the plant; and an older, mature to senescing leaf on the lower portion of the plant throughout the plant canopy to give representative average sample [9]. All the collected samples were transferred to the laboratory for chemical study.

\section{Relative Water Contents (RWC)}

RWC was determined by the methods used by previous researchers [3, 11, 12, 13]. Leaves were stored in a freezer inside plastic jars filled with water to saturate the leaves (a previously weighed plasticjar filled with water was used for each individual). They were stored for 8-9 h, i.e., the period needed to reach water saturation [14]. After saturation was achieved, the fresh weight of the leaves was obtained. Plastic jars were closed hermetically and were conserved in a freezer so that there was no loss of water. Then the leaves were weighed outside the jar in order to obtain their saturated weight (with $0.01 \mathrm{~g}$ precision). Finally they were oven-dried for $48 \mathrm{~h}$ at $70^{\circ} \mathrm{C}$ and weighed. The RWC (\%) was determined by the following formula:

$$
\text { RWC }(\%)=\{(\mathrm{Mf}-\mathrm{Md}) /(\mathrm{Mt}-\mathrm{Md})\} \times 100
$$

...where Mf is fresh mass, Md is dry mass after putting the leaves in an oven, and Mt is turgid mass after rehydrating the leaves. The leaf RWC takes into account the turgid mass of leaves and so it is the proportion of the leaf water content related to the maximum water content that can potentially be achieved by the leaf.

\section{Determining Total Chlorophyll Content}

The method described by previous researchers $[13,15]$ was used to calculate total chlorophyll contents from leaf samples. It was determined by using the $1 \mathrm{~g}$ powdered fresh leaf material in $10 \mathrm{ml}$ clean water after $10 \mathrm{ml}$ acetone was mix and then filtered it. Visual mass was noted at $\mathrm{D}_{645 \mathrm{~nm}}$ for chlorophyll "a" and $\mathrm{D}_{663 \mathrm{~nm}}$ for chlorophyll " $\mathrm{b}$ " on a spectrophotometer. Total chlorophyll content (T.Ch.) was determined by the following formula: 
Table 1. Standard of gradation level for APTI and responses.

\begin{tabular}{|c|c|c|c|}
\hline APTI & Value & Response & References \\
\hline A & $<11$ & Sensitive & $\begin{array}{c}\text { Padmavathi et } \\
\text { al. [32] }\end{array}$ \\
\hline B & $12-16$ & Intermediate & \\
\hline C & 17 & Tolerant & \\
\hline A & $30-100$ & Very Tolerant & $\begin{array}{c}\text { Prajapati and } \\
\text { Tripathi [18] }\end{array}$ \\
\hline B & $17-29$ & $\begin{array}{c}\text { Tolerant/Interme- } \\
\text { diate }\end{array}$ & \\
\hline C & $12-16$ & Intermediate & \\
\hline D & $01-11$ & Sensitive & \\
\hline E & $<1$ & Very Sensitive & \\
\hline
\end{tabular}

$$
\mathrm{TCh}=20.2\left(\mathrm{D}_{645 \mathrm{~nm}}\right)+8.02\left(\mathrm{D}_{663 \mathrm{~nm}}\right)
$$

... and $\mathrm{TCh}$ in $\mathrm{mg} / \mathrm{g}$ was determined by the following formula:

$$
\begin{gathered}
\text { TCh }(\mathrm{mg} / \mathrm{g} \mathrm{DW})=0.1 \times \mathrm{TCh} \\
\text { x (leaf Dw/leaf Fw) }
\end{gathered}
$$

\section{Ascorbic Acid Content}

A method described by Begum and Harikrishna [16] was used to measure ascorbic acid. One gram leaf sample and $3 \mathrm{ml}$ clean water was taken in the test tube. Then $4 \mathrm{ml}$ oxalic acid-EDTA $+1 \mathrm{ml}$ orthophosphoric acid, $1 \mathrm{ml} \mathrm{5 \%}$ tetraoxosulphate (VI) acid and $2 \mathrm{ml}$ ammonium molybedate was added in the test tube. The mixture was allowed to stand for 20 minutes after absorbance was noted at $760 \mathrm{~nm}$ on a spectrophotometer. Ascorbic acid concentration was expressed in $\mathrm{mg} / \mathrm{g}$.

\section{pH Determination}

A glass electrode $\mathrm{pH}$ meter was used to determine leaf extract $\mathrm{pH} .3 \mathrm{~g}$ of leaf material was added in $10 \mathrm{ml}$ clean water and then homogenized and filtered. $\mathrm{pH}$ calibration was made with buffer solution. Before the measurement of leaf extract $\mathrm{pH}$. The $\mathrm{pH}$ calibration was made with buffer solution at 4 and $9 \mathrm{pH}$ values [13].

\section{Measurement of APTI}

Techniques explained by Singh and Rao [17] were used for measuring APTI.

$$
\mathrm{APTI}(\mathrm{mg} / \mathrm{g})=\mathrm{AA}(\mathrm{Tch}+\mathrm{pH})+\mathrm{RW} / 10
$$

...where AA stands for ascorbic acid, Tch stand for total chlorophyll content, $\mathrm{pH}$ is for $\mathrm{pH}$ of leaf extract, and RW is for relative water contents of

\begin{tabular}{|c|c|c|c|}
\hline $\begin{array}{l}\text { Classifying } \\
\text { Character }\end{array}$ & Parameters & $\begin{array}{c}\text { Outline } \\
\text { of valuation }\end{array}$ & $\begin{array}{l}\text { Grading of } \\
\text { characters }\end{array}$ \\
\hline \multirow{7}{*}{ Tolerance } & \multirow{7}{*}{ APTI } & 01-04 & - \\
\hline & & $05-08$ & - \\
\hline & & $09-12$ & + \\
\hline & & $13-16$ & ++ \\
\hline & & $17-20$ & +++ \\
\hline & & $21-24$ & ++++ \\
\hline & & $25-28$ & +++++ \\
\hline \multirow{8}{*}{$\begin{array}{l}\text { Biological } \\
\text { and } \\
\text { socioeco- } \\
\text { nomic }\end{array}$} & \multirow{3}{*}{$\begin{array}{l}\text { Height of } \\
\text { plant }\end{array}$} & Minor & - \\
\hline & & Average & + \\
\hline & & Big & ++ \\
\hline & \multirow{3}{*}{$\begin{array}{c}\text { Structure of } \\
\text { canopy }\end{array}$} & Thin/rough/orbed & - \\
\hline & & $\begin{array}{l}\text { Dispersal crown/ } \\
\text { partial thick/open }\end{array}$ & + \\
\hline & & Dispersal thick & ++ \\
\hline & \multirow{2}{*}{ Plant type } & Deciduous & - \\
\hline & & Evergreen & + \\
\hline \multirow{8}{*}{$\begin{array}{l}\text { Structure of } \\
\text { Laminar }\end{array}$} & \multirow{3}{*}{ Size } & Small & - \\
\hline & & Medium & + \\
\hline & & Large & ++ \\
\hline & \multirow{2}{*}{ Texture } & Smooth & - \\
\hline & & Coriaceous & + \\
\hline & \multirow{3}{*}{ Economic } & $\leq 3$ uses & - \\
\hline & & 3 or more uses & + \\
\hline & & 5 or more uses & ++ \\
\hline
\end{tabular}
the leaf.

Table 2. Standard for the grading character to the plant species $[6,18]$.

Table 3. Standard of grad point for API $[6,18]$.

\begin{tabular}{|c|c|c|}
\hline Valuation classes & Scoring percentage & Grade point \\
\hline Not recommended & 30 & 0 \\
\hline Very poor & $31-40$ & 1 \\
\hline Poor & $41-50$ & 2 \\
\hline Moderate & $51-60$ & 3 \\
\hline Good & $61-70$ & 4 \\
\hline Very good & $71-80$ & 5 \\
\hline Excellent & $81-90$ & 6 \\
\hline Best & $91-100$ & 7 \\
\hline
\end{tabular}




\section{Evaluating Anticipated Performance Index}

For the anticipated performance index we used the methods described by Prajapati and Tripathi [18]. API values were calculated by combining the biological and socioeconomic characteristics of different investigated plant species with the resultant APTI values. The API based on character grading (+ or -$)$ fixed to the plant. The principles intended for API are specified in Tables 2 and 3.

\section{Statistical Analysis}

Statistical analysis of the biochemical parameters was done using SPSS software version 16.0.

\section{Results and Discussion}

\author{
Effect of Environmental Air Pollution \\ on the Biochemical Parameters of Leaves \\ of the Studied Tree Species
}

The influences of environmental air pollution on the biochemical parameters of the deliberated plant species within Quetta city and university campus are given in Figs 2a)-5a) and 2b)-5b). Leaf extract $\mathrm{pH}$ values were 4.53-6.23 in tree species and 5.38-6.18 in ornamental shrubs, while at the control site it was 4.8-5.5 and 4.8-5.7, respectively (Fig. 2a-b). The variations in $\mathrm{pH}$ values were marked and important $(\mathrm{p} \leq 0.05)$ in $F$. angustifolia Vahl. (6.23), which were followed by $R$. pseudoacacia L. (6.18), and the minimum was noted in $P$. vera L. (4.53). The high $\mathrm{pH}$ value was also reported by Leghari et al. [19] in different plant species. The high $\mathrm{pH}$ values in plants are recognized to develop tolerance levels against environmental pollution [20]. Due to the influence of ambient air pollution on $\mathrm{pH}$ levels, investigated plants showed the following sequence: F. angustifolia Vahl. $>$ R. pseudoacacia L. > M. nigra L. $>P$. halepensis Miller. $>P$. orientalis $\mathrm{L}$. $>$ M.alba L. > F. carica L. > P. armeniaca L. and M. pumila Miller $>P$. vera L., while ornamental shrubs showed non-significant variation with sequences: $R$. indica and D. barbeyi (Huth) $>C$. indica L. $>M$. jalapa L. and P. somniferum L. $>S$. alopecuroides L. $>J$. grandiflorum L. $>R$. acraeus $>$ G. rotandifolium L. $>$ $O$. basilicum L. Similar observations were reported by other researchers who found variations in $\mathrm{pH}$ values in different plant species [5].

Ascorbic acid (AA) contents obtained from examined plants are illustrated in Fig. 2b). The significant high AA contents were noted in the plants of polluted sites when compared to the control site, which might be due to the presence of large quantities of air pollutants at polluted sites. The finding of Kousar et al. 2014 [21] indicated that the AA contents of tree species increased because of air pollution. In this study, AA contents were noted $7.1-9.5 \mathrm{mg} / \mathrm{g}$ in tree species and $2.4-2.9 \mathrm{mg} / \mathrm{g}$ in shrubs at polluted sites, while at control sites the range was $4-6.3 \mathrm{mg} / \mathrm{g}$ and $1.3-2 \mathrm{mg} / \mathrm{g}$, correspondingly. Cheng et al. [22] exhibited the presence of high concentrations of AA service to increase the defensive system and tolerance levels in plants against air pollution, and the large quantity of ascorbic acid points out the great pollution levels in the area. It is too significant that levels of air pollution in the city site were great as shown by the results of AA in investigated tree species. Trees showed the following sequence due to the presence of AA contents in ambient air: P. vera L. $>P$. halepensis Miller., F. carica L. and P. halepensis Miller. $>P$. orientalis L. $>M$. nigra $>P$. armeniaca L. $>M$. alba L. and M. pumila Miller $>F$. angustifolia Vahl $>$ $R$. pseudoacacia L., while in ornamental shrubs it was: G. rotandifolium L. $>C$. indica L. and S. alopecuroides L. $>R$. indica $>D$. barbeyi (Huth) $>M$. jalapa L. and $P$. somniferum L. $>J$. grandiflorum L. $>R$. acraeus and $O$. basilicum $\mathrm{L}$. The finding of other researchers $[19,21,23]$ are consistent with these findings, but the observation recorded by Veni et al. [24] confirms our results as they reported a variation in AA values for different plant species. Sing et al. [25] reported that AA plays an important role in stopping the destructive action in plant tissues that occur due to air pollution. Rai and Panda [8] accounted for ascorbic acid and chlorophyll of leaf being the most significant and determining factors on which tolerance depends. The present finding is supported by the data $(0.35 \mathrm{mg} / \mathrm{g}$ and $2.39 \mathrm{mg} / \mathrm{g})$ reported from an industrial area of India for Eugenia jambolana and Psidium guajava [21].

The RWCs of leaves of the investigated plant species in two locations are presented in Fig. 4a-b). RWC showed significant variation across the locations in all the studied plant species. Variation in RWC for different plant species at different locations was also reported by Veni et al. [24]. In tree plants RWC was found between $79.3-89.2 \%$, and in ornamental shrubs it was $74.8-89.2 \%$, while at the control site the RWCs were found to be $80-88 \%$ and $72.5-87.4 \%$, respectively. The lowest RWC contents in tree species were noted in $M$. nigra $\mathrm{L}$. and the highest in $P$. vera $\mathrm{L}$. at polluted sites, while the ornamental shrubs showed the lowest contents for D. barbeyi (Huth) and the highest for S. alopecuroides L. The high RWC in plant leaves of urban sites was also recorded by Leghari et al. [19]. A high level of water in plant species indicted that maintenance of the physiological equilibrium in the stress of air pollution. The RWC is usually linked with the protoplasmic permeability of cells, which is intricate under the loss of water and melted nutrients in plants, which cause the dropping of leaves as stated by Tsega and DeviPrasad [26].

Total chlorophyll (T.Ch.) contents in the leaves of studied plant species significantly varied across the species and locations (Fig. 5a-b). The variation in total chlorophyll contents for trees and shrubs were also noted by Dhankhar et al., [7]. The highest T.Ch. contents (14.19 and 14.18) were found in the leaves of $P$. halepensis 
Fig. 2a)

Ascorbic acid (mg/g) in Tree Species

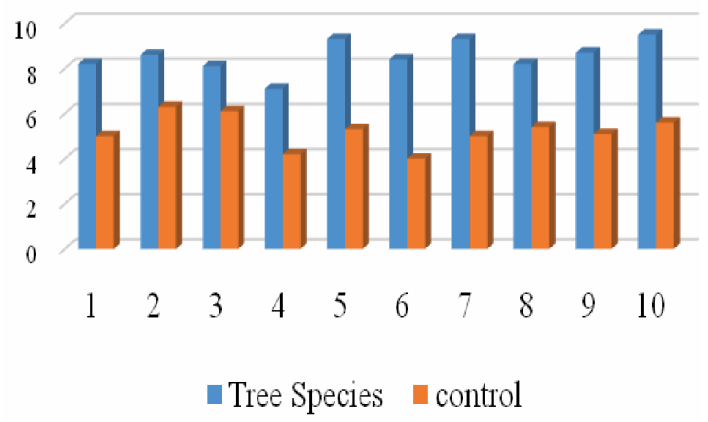

Fig. 2b) Ascorbic acid (mg/g) in omamental plant Species

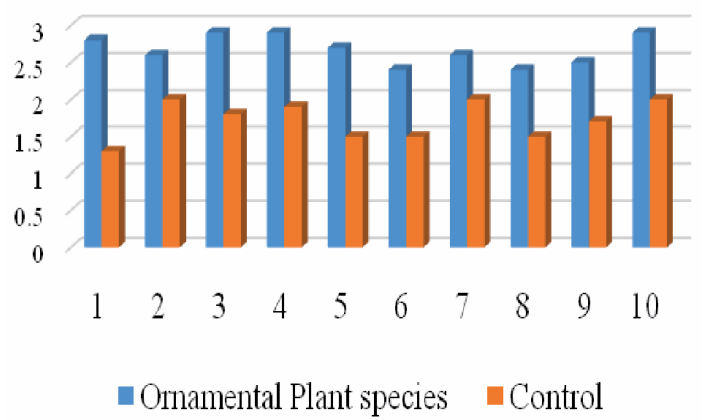

Fig. 3a)

$\mathrm{pH}$ in Leaf extract of Tree Species

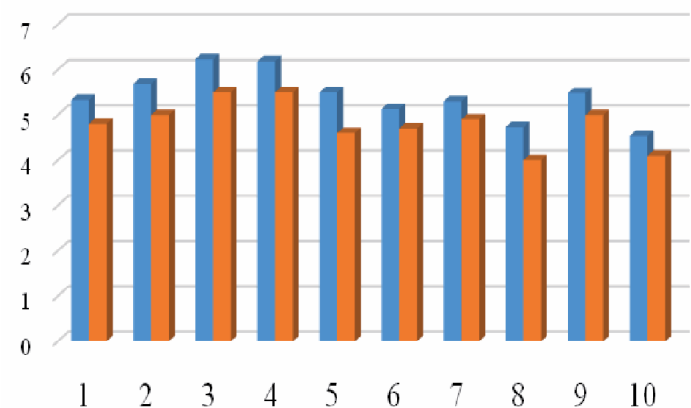

- Tree species $\quad$ Control

Fig. 3b) pH in Leaf extract of Omamental Species

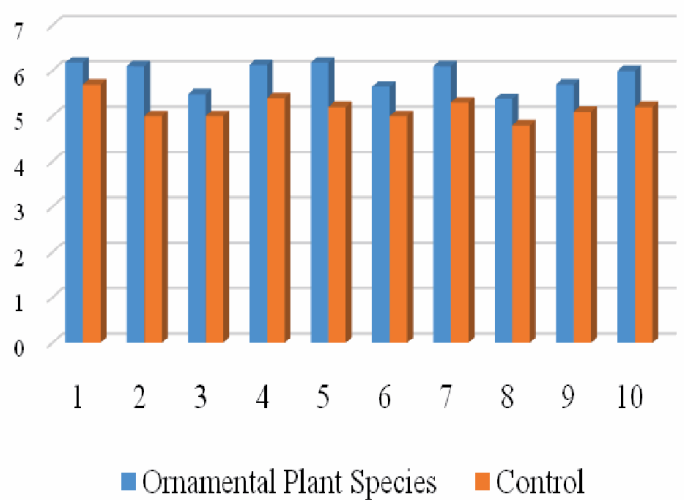

Fig. 4a)

RWC in Tree Species

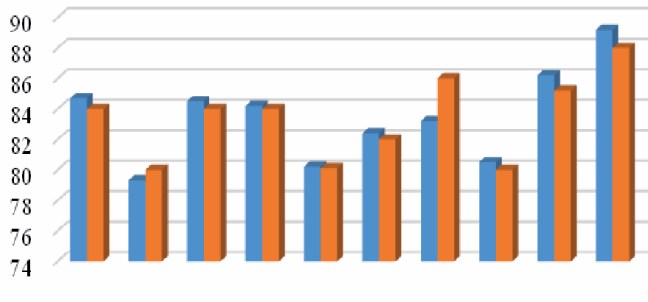

$\begin{array}{llllllllll}1 & 2 & 3 & 4 & 5 & 6 & 7 & 8 & 9 & 10\end{array}$

- Tree Plant species $\quad$ Control

Fig. 4b) RWC in Omamental Plant Species

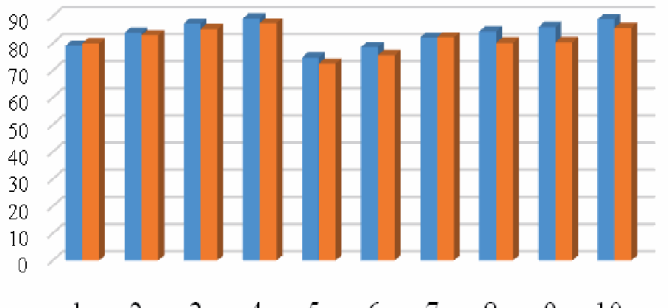

$\begin{array}{llllllllll}1 & 2 & 3 & 4 & 5 & 6 & 7 & 8 & 9 & 10\end{array}$

- Omamental Plant Species $\quad$ Contral

Fig. 5a)

T. Ch Contents in Tree Plant Species

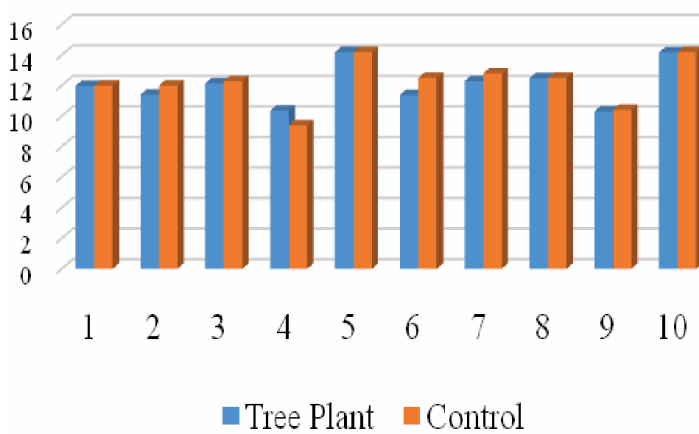

Fig. 5b) T. Ch Contents in Omamental Plant Species

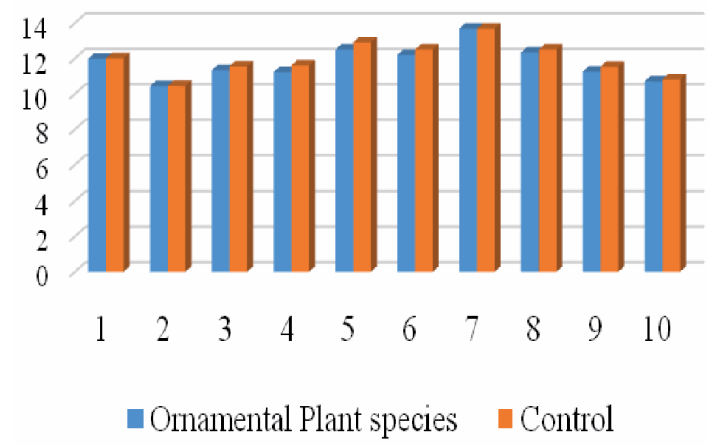

Fig. 2a)-5a) and 2b)-5b) show variation in mean value of 4 replicates. In figure 1a)-5a) 1 = M. alba L., $2=$ M. nigra L., $3=$ F. angustifolia Vahl., $4=$ R. pseudoacacia L., 5 = P. halepensis Miller., $6=$ P. armeniaca L. (Apricot), 7 = F. carica L. , $8=$ M. pumila Miller (Apple), $9=$ P. orientalis L., $10=$ P. vera L. while in figure 2 b)-5b) $1=$ R. indica, $2=$ M. jalapa L. $3=$ G. rotandifolium L. $4=$ C. indica L., $5=\mathrm{D}$. barbeyi (Huth), 6 = R. acraeus, 7 = P. somniferum L., 8 = O. basilicum L., 9=J. grandiflorum L.10 = S. alopecuroides L. 
Table 4. Assessment of plants according to their air pollution tolerance.

\begin{tabular}{|c|c|c|c|c|}
\hline Plant Name & Family & \multicolumn{2}{|c|}{ APTI values } & \multirow{2}{*}{ Assessment } \\
\hline \multicolumn{2}{|c|}{ Tree species } & Polluted site & Control site & \\
\hline Morus alba L. & Moraceae & 22.66 & 16.80 & Tolerant \\
\hline Morus nigraL. & Moraceae & 22.53 & 18.71 & Tolerant \\
\hline Fraxinus angustifolia Vahl. & Oleaceae & 23.29 & 19.26 & Tolerant \\
\hline Robinia pseudoacacia L. & Fabaceae & 20.39 & 14.68 & Tolerant \\
\hline Pinus halepensis Miller. & Pinaceae & 26.26 & 17.97 & Very Tolerant \\
\hline Prunus armeniaca $\mathrm{L}$. & Rosaceae & 22.10 & 15.08 & Tolerant \\
\hline Ficus carica $\mathrm{L}$. & Moraceae & 24.73 & 17.45 & Very Tolerant \\
\hline Malus pumila Miller. & Rosaceae & 22.20 & 16.91 & Tolerant \\
\hline Platycladus orientalis L. & Cupressaceae & 22.26 & 16.37 & Tolerant \\
\hline Pistacia vera $\mathrm{L}$. & Anacardiaceae & 26.74 & 19.05 & Very Tolerant \\
\hline \multicolumn{5}{|c|}{ Ornamental shrubs } \\
\hline Rosa Indica & Rosaceae & 13.02 & 10.30 & Intermediate \\
\hline Mirabilis jalapaL. & Nyctaginaceae & 12.69 & 11.39 & Sensitive \\
\hline Geranium rotandifolium $\mathrm{L}$. & Geraniaceae & 13.59 & 11.51 & Intermediate \\
\hline Canna indica $\mathrm{L}$. & Cannaceae & 13.95 & 11.97 & Intermediate \\
\hline Delphinium barbeyi (Huth) & Ranunculaceae & 12.56 & 09.97 & Sensitive \\
\hline Ranunculus acraeus & Ranunculaceae & 12.10 & 10.19 & Sensitive \\
\hline Papaver somniferum $\mathrm{L}$. & Papaveraceae & 13.40 & 12.01 & Intermediate \\
\hline Ocimum basilicumL. & Lamiaceae & 12.68 & 10.62 & Sensitive \\
\hline Jasminum grandiflorum $\mathrm{L}$. & Oleaceae & 12.83 & 10.87 & Sensitive \\
\hline Sophora alopecuroidesL. & Fabaceae & 13.73 & 11.77 & Intermediate \\
\hline
\end{tabular}

Miller. And $P$. vera L., respectively at polluted site and approximately equal contents (14.2) were found at control site for the tree species. From the ornamental shrubs $P$. somniferum L. showed maximum T.Ch. contents (13.68) at a polluted site. A similar observation was also reported by Dhankhar et al. [7] among the tree species they found highest chlorophyll contents in Azadirachta indica and the lowest in S. cimuni, and in the case of shrubs the highest contents were recorded in Gelsemum sempervirens. The minimum T. Ch. contents in tree species were noted in $R$. pseudoacacia $\mathrm{L}$. and $P$. orientalis L., and in ornamental shrubs it was found in $R$. indica (10.43). In the present study the high chlorophyll content was recorded in $P$. halepensis Miller, and $P$. vera L. might exhibit tolerance to air pollution because the high level of total chlorophyll in plants increases the tolerance level to the pollutants.

\section{Assessing APTI and API of Plant Species for Green Belt Development}

All the studied trees showed higher APTI values as compared to the ornamental shrubs (Table 4). But a study conducted by Yan-Ju and Hui [20] contradicts the current results as they reported higher values of APTI in ornamental shrubs than the tree species. This variation might be due to differences in study locations and climatic variation. The present study was conducted in Pakistan, while Yan-Ju and Hui worked in China. The mean values of APTI indicated that $P$. vera $\mathrm{L}$. (26.74) had the highest values, followed by $P$. halepensis Miller (26.26) among the tree species, and from ornamental shrubs the highest value was found in $C$. indica L. (13.95). The findings of Dwevidi and Tripathi [27] are in favor of the current results. They reported the highest APTI value (81.10) for the trees of severely polluted areas. The lowest APTI value (20.39) among trees was found for $R$. pseudoacacia L., and among ornamental shrubs it was for $R$. acraeus (12.10). The low APTI values reported in ornamental shrubs are more sensitive to air pollutants and can be suggested as bio-indicators. Ogunkunle et al. [5] also reported the lowest APTI values such as 7.80, 9.56, and 10.95 for $V$. paradoxa, $P$. Africana, and A. nilotica, respectively. Out of ten trees only three trees fall in very tolerant groups and the other 7 species showed 
Table 5. Comparison of temperature between under and outside canopy with APTI values.

\begin{tabular}{|c|c|c|c|}
\hline Plant Species & $\begin{array}{c}\text { Under-Canopy Temperature } \\
\text { (Mean value) }\end{array}$ & $\begin{array}{l}\text { Outside Canopy Temperature } \\
\text { (Mean value) }\end{array}$ & APTI \\
\hline \multicolumn{4}{|c|}{ Tree species } \\
\hline Morus alba L. & 12 & 15 & $22.66 \pm 1.38$ \\
\hline Morus nigra $\mathrm{L}$. & 12 & 15 & $22.53 \pm 0.50$ \\
\hline Fraxinus angustifolia Vahl. & 13 & 17 & $23.29 \pm 0.51$ \\
\hline Robinia pseudoacacia L. & 13 & 19 & $20.39 \pm 0.41$ \\
\hline Pinus halepensis Miller. & 12 & 15 & $26.26 \pm 0.44$ \\
\hline Prunus armeniaca $\mathrm{L}$. & 14 & 18 & $22.10 \pm 0.31$ \\
\hline Ficus carica $\mathrm{L}$. & 11 & 15 & $24.73 \pm 0.29$ \\
\hline Malus pumila Miller. & 13 & 15 & $22.20 \pm 0.29$ \\
\hline Platycladus orientalis L. & 17 & 20 & $22.26 \pm 0.56$ \\
\hline Pistacia vera $\mathrm{L}$. & 12 & 15 & $26.74 \pm 0.45$ \\
\hline \multicolumn{4}{|c|}{ Ornamental shrubs } \\
\hline Rosa Indica & 17 & 18 & $13.02 \pm 1.37$ \\
\hline Mirabilis jalapa L. & 18 & 19 & $12.69 \pm 0.37$ \\
\hline Geranium rotandifolium $\mathrm{L}$. & 20 & 20 & $13.59 \pm 0.79$ \\
\hline Canna indica $\mathrm{L}$. & 20 & 21 & $13.95 \pm 0.41$ \\
\hline Delphinium barbeyi (Huth) & 20 & 20 & $12.56 \pm 0.31$ \\
\hline Ranunculus acraeus & 22 & 22 & $12.10 \pm 0.40$ \\
\hline Papaver somniferum L. & 17 & 18 & $13.40 \pm 0.20$ \\
\hline Ocimum basilicum L. & 20 & 20 & $12.68 \pm 0.26$ \\
\hline Jasminum grandiflorum L. & 22 & 22 & $12.83 \pm 0.26$ \\
\hline Sophora alopecuroides L. & 22 & 23 & $13.73 \pm 0.41$ \\
\hline
\end{tabular}

the only tolerant group, and from ornamental shrubs 5 species fall in intermediate and another 5 species were a sensitive group. Kousar et al. [21] reported that the sensitive species are ideal bio-indicators and tree plants by great APTI level is lenient toward air pollutants [26] and they are utilized as filters. Data reported by some other workers are in support of our results [28, 29]. On the basis of APTI values the tree species showed the following sequence: $P$. vera L. $>P$. halepensis Miller. $>F$. carica L. $>F$. angustifolia Vahl $>M$. alba L. $>$ M. nigra L. $>$ P. orientalis L. $>$ M. pumila Miller (Apple) $>$ P. armeniaca L. > R. pseudoacacia L., and ornamental plant species showed the following sequence: Canna indica L. > S. alopecuroides L. > G.rotandifolium L. > $P$. somniferum $\mathrm{L}$. and $R$. indica $>J$. grandiflorum $\mathrm{L} .>$ M. jalapa L. $>$ O.basilicum L. $>D$. barbeyi (Huth) $>R$. acraeus.

Temperatures under and outside the canopy showed significant variation (Table 5). Under canopy temperature under tree species was in the range of $11-17^{\circ} \mathrm{C}$ while it increased by $15-20^{\circ} \mathrm{C}$ outside the canopy. Low temperatures under the canopy and high outside the canopy was also reported by Enete et al., [30].

Results presented in Table 6 evaluated the grading of 20 different plant species (trees and ornamental shrubs) depending on the APTI and pertinent socioeconomic and biological characteristics. The present study indicated that four tree species such as $M$. alba L., $P$. halepensis Miller., F. carica L., and P. vera L. showed the higher grade $(81.25 \%)$ each with 13 plus, which were followed by $M$. nigra L. and M. pumila Miller showing grade $75.00 \%$ with 12 plus each. The lowest grade $(50.00 \%)$ with 8 plus was noted in $R$. pseudoacacia L. From ornamental shrubs the highest grade (37.50\%) scored by Rosa indica and Papaver somniferum L. with 06 plus, and the lowest grade $(06.25 \%)$ was gained by Delphinium barbeyi (Huth) and Jasminum grandiflorum L. with 01 plus. (Table 6).

The API assessment of the tree species showed that V. paradoxa could be an ideal species for green belts, especially in urban areas, in order to alleviate pollution and make significant contributions to the ecosystem. 
Table 6. Evaluation of APTI values and biological and socioeconomic characters.

\begin{tabular}{|c|c|c|c|c|c|c|c|c|c|c|}
\hline \multirow[b]{2}{*}{ Plant Names } & \multirow[b]{2}{*}{ APTI } & \multicolumn{3}{|c|}{ Biological and socioeconomic } & \multicolumn{2}{|c|}{ Laminar } & \multirow{2}{*}{$\begin{array}{l}\text { Economic } \\
\text { importance }\end{array}$} & \multirow{2}{*}{$\begin{array}{c}\text { Hard- } \\
\text { ness }\end{array}$} & \multicolumn{2}{|c|}{ Grade allotted } \\
\hline & & $\begin{array}{l}\text { Plant } \\
\text { habit }\end{array}$ & $\begin{array}{l}\text { Canopy } \\
\text { structure }\end{array}$ & $\begin{array}{c}\text { Type of } \\
\text { Plant }\end{array}$ & Texture & Size & & & $\begin{array}{c}\text { Total } \\
\text { plus }(+)\end{array}$ & $\begin{array}{c}\% \\
\text { Scoring }\end{array}$ \\
\hline \multicolumn{11}{|c|}{ Tree Species } \\
\hline Morus alba $\mathrm{L}$. & ++++ & ++ & ++ & - & + & ++ & + & + & 13 & 81.25 \\
\hline Morus nigra L. & ++++ & ++ & ++ & - & + & + & + & + & 12 & 75.00 \\
\hline Fraxinus angustifolia Vahl. & ++++ & ++ & + & - & + & + & - & + & 10 & 62.50 \\
\hline Robinia pseudoacacia L. & +++ & ++ & + & - & + & - & - & + & 08 & 50.00 \\
\hline Pinus halepensis Miller. & +++++ & ++ & ++ & + & + & + & - & + & 13 & 81.25 \\
\hline Prunus armeniaca $\mathrm{L}$. & ++++ & + & + & + & - & + & + & + & 10 & 62.50 \\
\hline Ficus carica $\mathrm{L}$. & ++++ & ++ & + & + & + & ++ & + & + & 13 & 81.25 \\
\hline Malus pumila Miller. & ++++ & + & + & + & + & + & + & + & 12 & 75.00 \\
\hline Platycladus orientalis L. & ++++ & ++ & + & ++ & - & + & - & + & 11 & 68.75 \\
\hline Pistacia vera $\mathrm{L}$. & +++++ & + & ++ & ++ & - & + & + & + & 13 & 81.25 \\
\hline \multicolumn{11}{|c|}{ Ornamental plant species } \\
\hline Rosa indica & ++ & + & - & - & + & + & + & - & 06 & 37.50 \\
\hline Mirabilis jalapa $\mathrm{L}$. & + & - & - & - & + & - & - & - & 02 & 12.50 \\
\hline Geranium rotandifolium $\mathrm{L}$. & ++ & - & - & - & + & - & - & - & 03 & 18.75 \\
\hline Canna indica $\mathrm{L}$. & ++ & - & + & - & - & + & - & - & 03 & 18.75 \\
\hline Delphinium barbeyi (Huth) & + & - & - & - & - & - & - & - & 01 & 06.25 \\
\hline Ranunculus acraeus & + & - & - & - & + & - & + & - & 03 & 18.75 \\
\hline Papaver somniferum L. & ++ & - & + & - & + & + & + & - & 06 & 37.50 \\
\hline Ocimum basilicum $\mathrm{L}$. & + & - & - & - & - & - & + & - & 02 & 12.50 \\
\hline Jasminum grandiflorum $\mathrm{L}$. & + & - & - & - & - & - & - & - & 01 & 06.25 \\
\hline Sophora alopecuroides L. & ++ & - & + & - & - & - & - & - & 03 & 18.75 \\
\hline
\end{tabular}

Results of the API in Table 7 showed that $M$. alba L., P. halepensis Miller., F. carica L., and P. vera L. can be anticipated to be excellent performers, and $M$. nigra $\mathrm{L}$. and $M$. pumila Miller indicated that they are very good for the development of a green belt. Other three trees $F$. angustifolia Vahl., P. armeniaca L., and $P$. orientalis L. are good for green belts in the investigated areas, while $R$. pseudoacacia L. were reportedly poorer in the tree species. Ogunkunle et al. [5] suggested that tree species with high API values are very good for the green belt formation. All the investigated ornamental shrubs were found to be very poor and are not recommended for green belts, while they are considered as good bioindicators for air pollution. The observations reported by Laskshmi [8] are similar to the present results. They reported that the subtle species support in representative for environmental pollution and lenient ones service in the reduction of environmental pollution. Nugrahani et al. [31] designated that the tree and ornamental plant variety standards are gifted to support the improvement of air standards through having great air pollution resistant quality.

\section{Conclusions}

This study indicated that the valuation of simply the APTI value for plant species may not be perfect for mentioning plants for greenbelt development, and that the grouping of APTI and API can be of massive significance. It is obvious from this study that the only principle of the biochemical parameters played a unique role in determining the reply of plants (trees and shrubs) species to air pollution but may not be ideal for evaluating plant responses to a variety of pollutants for green belt purposes. However, using a combination of the biochemical parameters (APTI), biological and socioeconomic characteristics has verified the possibility of endorsing plant species for green belt purposes. On the basis of APTI and API assessment, this study suggests that plant species such 
Table 7. Anticipated performance index (API) value of the studied tree species.

\begin{tabular}{|c|c|c|c|c|}
\hline \multirow{2}{*}{ Name of Plant species } & \multicolumn{2}{|c|}{ Grade } & \multirow{2}{*}{ API values } & \multirow{2}{*}{ Assessment } \\
\hline & Total plus $(+)$ & Percentage $(\%)$ & & \\
\hline \multicolumn{5}{|c|}{ Tree Species } \\
\hline Morus alba $\mathrm{L}$. & 13 & 81.25 & 6 & Excellent \\
\hline Morus nigra L. & 12 & 75.00 & 5 & Very good \\
\hline Fraxinus angustifolia Vahl. & 10 & 62.50 & 4 & Good \\
\hline Robinia pseudoacacia L. & 08 & 50.00 & 2 & Poor \\
\hline Pinus halepensis Miller. & 13 & 81.25 & 6 & Excellent \\
\hline Prunus armeniaca $\mathrm{L}$. & 10 & 62.50 & 4 & Good \\
\hline Ficus carica $\mathrm{L}$. & 13 & 81.25 & 6 & Excellent \\
\hline Malus pumila Miller. & 12 & 75.00 & 5 & Very good \\
\hline Platycladus orientalis L. & 11 & 68.75 & 4 & Good \\
\hline Pistacia vera $\mathrm{L}$. & 13 & 81.25 & 6 & Excellent \\
\hline \multicolumn{5}{|c|}{ Ornamental Plant species } \\
\hline Rosa Indica & 06 & 37.50 & 1 & Very poor \\
\hline Mirabilis jalapa $\mathrm{L}$. & 02 & 12.50 & 0 & Not recommended \\
\hline Geranium rotandifolium L. & 03 & 18.75 & 0 & Not recommended \\
\hline Canna indica $\mathrm{L}$. & 03 & 18.75 & 0 & Not recommended \\
\hline Delphinium barbeyi (Huth) & 01 & 06.25 & 0 & Not recommended \\
\hline Ranunculus acraeus & 03 & 18.75 & 0 & Not recommended \\
\hline Papaver somniferum L. & 06 & 37.50 & 1 & Very poor \\
\hline Ocimum basilicum L. & 02 & 12.50 & 0 & Not recommended \\
\hline Jasminum grandiflorum L. & 01 & 06.25 & 0 & Not recommended \\
\hline Sophora alopecuroides L. & 03 & 18.75 & 0 & Not recommended \\
\hline
\end{tabular}

as $P$. halepensis, F. carica, $P$. vera, M. alba, M. nigra, and $M$. pumila are perfect for ecological purposes in the study area.

\section{Acknowledgements}

This research was supported by University of Balochistan Research Fund (UBRF-17/013).

\section{Conflict of Interest}

The author declares no conflict of interest.

\section{References}

1. LEGHARI S.K., ASRAR M., MUHAMMAD A., RAHMAN S., ILAHI Z. Impact of Air Pollution Caused By Fire Smoke on Yield And Nutritional Value of
Pleurotus (Flabellatus) Djamor, R-22., Pak. J. Bot., 49 (SI), 279, 2017.

2. LOHE R.N., TYAGI B., SINGH V., KUMAR P.T., KHANNA D.R., BHUTIANI A., Comparative study for air pollution tolerance index of some terrestrial plant species., Global J. Environ. Sci. Manage. 1, 315, 2015.

3. CHAUDHRY S., PANWAR J. Evaluation of Air Pollution Status and Anticipated Performance Index of some Tree Species for Green Belt development in the holy city of Kurukshetra, India. Int. J. Innov. Res. Sci. Technol. 2, 269, 2016.

4. ENETE I.C., ALABI M.O., CHUKWUDELUNZU V.U. Tree Canopy Variation effects on urban heat Island in Enugu City, Nigerian. Developing Country Studies, 2, 12, 2012.

5. OGUNKUNLE C.O., SULEIMAN L.B., OYEDEJI S., AWOTOYE O.O., FATOBAPO. Assessing the air pollution tolerance index and anticipated performance index of some tree species for biomonitoring environmental health. Agroforest Syst. 89:447, 2015.

6. GOVINDARAJU M., GANESHKUMAR R.S., MUTHUKUMARAN V.R., VISVANATHAN P. 
Identification and evaluation of air-pollution tolerant plants around lignite-based thermal power station for greenbelt development. Environ. Sci. Pollut. Res. 19, 1210, 2012.

7. DHANKHAR R., MOR V., NARWAL S. Anticipated performance index of selected plant species in University campus area, Rohtak, Haryana, India. Int. J. Adv. Multidiscip. Res. 2, 32, 2015.

8. RAI P.K., PANDA S. Dust capturing potential and air pollution tolerance index (APTI) of some road side tree vegetation in Aizawl, Mizoram, India: an Indo-Burma hot spot region. Air Qual. Atmos. Health, 7, 93, 2014.

9. LAGHARI S.K., ZAIDI M.A. Effect of air pollution on the leaf morphology of common plant species of Quetta city. Pak. J. Bot. 45 (S1), 447, 2013.

10. ARA F., IQBAL Z.M., QURESHI M.S. Determination of heavy metals concentrations of trees and soil due to vehicular emission in Karachi city. Kar. Univ. J. Sci., 24, 80, 1996.

11. MUNNE- BOSH S., PENUELAS J. Drought- induced oxidative stress in strawberry tree (Arbutus unedoL.) growing in Mediterranean field conditions. Plant Sciences 166, 1105, 2004.

12. LEGHARI S.K., ZAIDI M.A., SARANGZAI A.M. Seasonal Variation In Leaf Relative Water, Dry Matter And Live Fine Fuel Moisture Contents In Some Common Plant Species Of Quetta, Balochistan., FUUAST J. BIOL., 3(2), 73, 2013.

13. AGBAIRE PO., ESIEFARINRHE E. Air Pollution tolerance indices of some plants around Otorogum gas plants in Delta State, Nigeria. J. Appl. Sci. Environ. Management 13, 11, 2009.

14. ESPILTA J.M. La regenaracio de bassos d;alzina (Quorums ilex L) pipe blanks (Pinus helepensis Mill): estudi experimental de la resposta de less plantules a la intensitat de llum I a la disponibilitat d'aigua PhD Thesis; (Autonomous University of Barcelonna, spain), 1996.

15. CHOUHAN A., IQBAL S., MAHESHWARI R.S. A study of air pollution tolerance index of plants growing in Pithampur industrial area sector 1, 2 and 3. Res. J. Recent Sci. 1, 172, 2012.

16. BEGUM A., HARIKRISHNA S. Evaluation of some tree species to absorb air pollutants in three industrial locations of South Bengaluru, India. E-J Chem. 7, 151, 2010.

17. SINGH S.K., RAO D.N. Evaluation of plants for their tolerance to air pollution, proceedings of the symposium on air pollution control, 218, 1983.

18. PRAJAPATI S.K., TRIPATHI B.D. Anticipated performance index of some tree species considered for green belt development in and around an urban area: a case study of Varaasi city, India. J. Environ. Manage. 88, 1343, 2008.

19. LEGHARI S.K., ZAIDI M.A., AHMED M., NAZIM K. Air pollution tolerance index (APTI) of various Plant species growing in Quetta city Pakistan. FUUAST J. Biol., 1, 81, 2011.

20. YAN-JU L., HUI D. Variation in air pollution tolerance index of plants near steel factory. Implication for landscape-plant species selection for industrial areas. Environ. Develop., 1, 24, 2008.

21. KOUSAR H., NUTHAN K.D., PAVITHRA K., ADAMSAB M.P. Analysis of biochemical parameters as tolerance index of some chosen plant species of Bhadravathi town. Int. J. Environ. Sci. 3, 11, 2014.

22. CHENG F.Y., BURKEY K.O., ROBINSON J.M., BOOKER F.L. Leaf extracellular ascorbate in relation to ozone tolerance of two soya bean cultivars. Environ. Pollut. 150,355, 2007.

23. BERMADINGER E., GUTTENBERGER H., GRILL D. Physiology of young Norway spruce. Environ. Pollut. 68, 319, 1990.

24. VENI K., MARIMUTHU, LAVANYA K. Air Pollution Tolerance Index Of Plants A Comparative Study. Int J Pharm. Sci. 6, 320, 2014.

25. SINGH SK., RAO D.N., AGRAWAL M., PANDE J., NARAYAN D. Air pollution tolerance index of plants. J. Environ. Manag. 32, 45, 1991.

26. TSEGA Y.C., DEVI-PRASAD A.G. Variation in air pollution tolerance index and anticipated performance index of roadside plants in Mysore, India. J. Exp. Biol. 35, 185, 2014.

27. DWEVIDI A.K., TRIPATHI B.D. Pollution tolerance and distribution pattern of plants in surrounding area of coalfired industries. J. Environ. Biol. 28, 257, 2007.

28. CHAUHAN R.G. Tree as bio-indicator of automobile pollution in Dehradum City. A Case Study. J.New York Sci. 3, 88, 2010.

29. ABIDA B., HARIKRISHNA S. Evaluation of some tree species to absorb air pollutants in three in dustrial locations of South Bengaluru, India. E-Journal of Chem., 7 (S1), 51, 2010.

30. ENETE I.C., OGBONNA C.E., OFFICHA M.C. Using trees as urban heat island reduction tool in Enugu City, Nigeria based on their air pollution tolerance index. Ethopian J. of Environ. Stud. Manage. 5, 484, 2012.

31. NUGRAHANI P., PRASETYAWATI E. T., SUGIJANTO O., PUMOBASUKI H. Asian J. Biol. Sci. 3, 298, 2012.

32. PADMAVATHI P., CHERUKURI J., REDDY M.A. Impact of air pollution on crops in the vicinity of a power plant: a case study. Int. J. Eng. Res. Technol. 2, 3641, 2013. 